\title{
The Effect of Google Earth Utilization on Students' Spatial Thinking Ability
}

\author{
Sri Rahayu, Murjainah, M. Idris \\ Department of Geography Education, University of PGRI Palembang \\ Jln. Jend. A. Yani, Lr Gotong Royong 9/10 Ulu, 30116, Palembang, Indonesia \\ Email : Srirahayu9796@gmail.com
}

Received 1 August 2019/ Revised 2 December 2019/ Accepted 5 December 2019/ Published 12 December 2019

\begin{abstract}
The ability to think spatially in geography learning is essential, so it requires technology-based learning resources in the form of google earth, which can facilitate students in imagining or visualizing images in mind. In this regard, this study aims to determine the effect of the use of google earth on the spatial thinking abilities of students in the class X Geography of SMA PGRI 2 Palembang. This study used an experimental research method (Posttest-Only Control Design), because this design is suitable to use if the pre-test is not possible or pre-test can influence the experimental. The sample data collection technique uses Purposive Sampling, which is based on considerations or criteria that must be met by the sample used in the study. The sample in this study is class X IPS 1 as the experimental class and X IPS 2 as the control class. Data collection techniques used documentation and tests. For data analysis techniques, normality test, homogeneity test, and hypothesis testing using the IBM SPSS Statistics 20 formula for Windows. Based on the results of the study, the average value of the experimental class's superior post-test was 82.92, and the results of the posttest control class were 66.39. It shows that there are differences in the spatial thinking ability of the experimental group students who were treated using Google Earth during the learning process. The significance of the results of the posttest t-test from the two experimental and control groups was 0.000 , and then the null hypothesis Ho was declared rejected because based on the t-test criteria, the significance value was $<0.05$ or the Sig (2-tailed) value of 0,000 was obtained $<0.05$. So it can be concluded that there is a significant influence between the use of google earth on the spatial thinking ability of students in the class X Geography subject of SMA PGRI 2 Palembang.
\end{abstract}

Keywords: Google Earth, Spatial Thinking Ability, Geography.

\section{Introduction}

Spatial thinking is recognized as a collection of three cognitive skills about the nature and concepts of space (such as distance, closeness, and distribution), about the representation of spatial information (such as maps and graphs), and the process of spatial reasoning (such as decision making) (Support Committee for Thinking Thinking Spatial; Liu, et al. 2019). Spatial 
ability according to Albert and Golledge; Setiawan (2015) consists of spatial visualization, spatial orientation and spatial relationships. In fact, according to Golledge \& Stimson; Halpern; Aliman, Mutia \& Yustesia (2018) Spatial thinking is the ability of human reasoning to recognize spaces that can develop due to input, processing and output processes. According to the National Research Council, 2006; Setiawan (2015) Spatial thinking is one form of thought among other types of view, such as verbal, logical, statistical, hypothetical and so on.

Furthermore, spatial thinking is an important character in Geography learning activities. According to Setiawan (2015), the study of geographic phenomena not only explains the existence of a phenomenon and the process of occurrence of this phenomenon on the surface of the earth but also the shape, size, direction, pattern of phenomena and their relationship with other phenomena. According to Hidayat et al (2017), spatial thinking is a basic skill that can be accessed by everyone to different degrees in different contexts to solve problems in various contexts. Meanwhile according to Lee Jongwon \& Bednars S Robert; Hidayat et al (2017) spatial thinking requires three related components, namely: the concept of space, the method used to represent spatial information, and the process of spatial reasoning. Therefore, these three components are interrelated, mutually supportive and inseparable.

The importance of spatial thinking can and must be taught at all levels in the education system. The goal is that each individual has the good spatial ability. Gersmehl \& Gersmehl; Oktavianto et al (2017) define spatial thinking as an ability that can be used by a geographer to analyze spatial relationships on earth. This ability will be very useful for students when deciding or making decisions from things that are very simple to complications related to space or location. When someone travels, he must know about distance and direction, so he can predict the time of arrival and not get lost. Therefore, in learning Geography, it is very important to emphasize spatial thinking, not only information about geographic phenomena, but students must have the ability to analyze spatial aspects, because the ability of spatial thinking in Geography can affect students' ability to imagine or visualize images in the mind.

Based on data obtained from Geography subject teachers in class X SMA PGRI 2 Palembang, said that there were 4 class X social studies, where $60 \%$ of students in grade 10 had reached KKM with a score above 70 , while $40 \%$ of students had not yet reached KKM. Core Competencies of Geography subject in class $\mathrm{X}$ are managing, reasoning, and presenting in the abstract realm related to the development of what is learned in schools independently and can 
use methods that are following curriculum rules. The basic competency used is to present the results of an analysis of the relationship between humans and their environment as the influence of atmospheric dynamics in the form of narratives, tables, graphs, graphs, illustrated images, and concept maps. Then, Indicators identify the type of inland waters, identify the use of inland waters, analyze conservation of inland waters, and watersheds. A watershed is a part of the earth's surface where water flows into certain rivers. In other words, a watershed is a rainwater reservoir that enters the watershed. Watershed consists of 3 types, namely upstream, downstream and middle watersheds.

In this connection, the teacher's role becomes important in learning to improve students' spatial abilities. The teacher is expected to be able to provide stimulation to students and interesting innovations and learning strategies are needed so that students can understand the Geography concept about watersheds in Southern Sumatera, so that it can be understood more easily. Recognizing that all technological facilities are needed, that can improve spatial thinking skills. So, it is needs technology that can support learning, using Google Earth. According to Yousman (2008) Google Earth is an interactive mapping application released by Google. Google earth displays globe maps, topography, satellite photos, terrain that can be overlaid with roads, buildings, locations, or other geographical information. With Google Earth, we can plan trips, find tourist attractions, motorbikes, restaurants, hotels, hospitals, schools and more where we can get latitude and longitude coordinates. Google earth can display low-resolution satellite photos that depict mountains, seas, forests, to high-resolution satellite photos that can depict objects such as roads, office homes. For certain areas that are already equipped with 3D building views.

Google earth provides an application for educators to display images of the earth visually. Google earth also provides opportunities for students to see every side of the world. Google earth helps students see distance and other geographical features. Google Earth is a free software package available for anyone who has a computer and an internet connection. This is an online resource available in the classroom and can be used by students at home. Studies have shown that the use of online resources has helped increase students' understanding of key concepts and skills while also helping students gain confidence in their knowledge of geographical problems (Solem and Gersmehl; Cuviello, 2010). According to Bodzin et al. (2009); Oktavianto et al. (2017) Geospatial-based sites such as Google Earth can accelerate the improvement of spatial thinking skills in a variety of students. This is in line with the main material in this study that 
requires digital technology facilities with easy access to information that is relatively faster without having to be present directly on the object to be addressed.

The novelty in this study is analysis regarding Google Earth for conveying material taught specifically in Geography. Bearing in mind that many students find it difficult to understand an object or map if they learn to use ordinary maps, so the teacher is required to more attention for help students develop their own spatial thinking skills so as to achieve the expected competencies in learning geography in school. Based on these problems, the reference for researcher to conducting research on the effect of using Google Earth to students' spatial thinking abilities. The purpose of this study was to determine the effect of using Google Earth to students' spatial thinking abilities.

\section{Methods}

The method used in this study is the Experimental research method in the form of Posttest Only Control Design (Sugiyono, 2010). Data collection of this study uses test techniques. The test is given at the end of the meeting, used to obtain data on the ability of students to solve the questions given after using Google Earth. The test used is a multiple-choice form test.Validity test using the IBM SPSS Statistics 20 formula for Windows. Testing the validity of the instrument in this study uses the validity of construction, namely the Pearson productmoment correlation formula as follows:

$$
\mathrm{R}_{\mathrm{xy}}=\frac{n \Sigma X Y-(\Sigma X)(\Sigma Y)}{\sqrt{\left\{\left(\Sigma X^{2}\right)-(\Sigma X)^{2}\right\}\left\{N \Sigma Y^{2}-(\Sigma Y)^{2}\right\}}}
$$

(Arikunto,2010)

Reliability testing is done using IBM SPSS Statistics 20 for Windows with the Cronbach's Alpha model, which is measured on the Cronbach's Alpha scale 0 to 1 . To find the reliability value using Alpha formula:

$$
r_{11}=\frac{k}{k-1} \times\left\{1-\frac{\sum S_{i}}{S_{t}}\right\}
$$

(Arikunto,2010)

The data analysis technique used in this study is the statistical test parameter $t$ ( $t$ test). The $t$ statistical test is used to test the rejection or acceptance of the null hypothesis, provided that the sample is homogeneous and normally distributed. The value of the geography learning test 
results obtained in the experimental class and the control class. According to Sudjana Test t-test (2005) as follows:

$$
\mathrm{S}_{\mathrm{gab}}=\sqrt{\frac{\left(n_{1}-1\right) S_{1}^{2}+\left(n_{2} 1\right) S_{1}^{2}}{n_{1}+n_{2}-2}}
$$

(Sudjana, 2005)

Normality test to analyze data by testing whether the data obtained is normal or not. Data normality test needs to be done to find out whether the data analyzed is normal or not. Data is said to be normal if the $\mathrm{km}$ price is located between $1(-1 \leq \mathrm{km} \leq 1)$. The data created in the frequency distribution table is tested for normality using the curve slope normality test formula as follows:

$$
K m=\frac{X-M o}{S}
$$

Homogeneity test data is done to prove the similarity of group variance, where samples taken are from the same population. To test the sample using the Bertlett test with the chi-square equation. At the beginning of the meeting in the experimental class, students look confused in the following learning because the delivery of learning has never used Google Earth so that the beginning of learning researchers are active to guide students during the learning process by using Google Earth. After researchers explain how to use Google Earth, students become more active. The use of Google Earth helps researchers in delivering material well so that students become more focused on visualizing images. The water inland described by researchers in the form of rivers, lakes and swamps makes students interested in listening carefully. This is proven by the good results when students work on the posttest.

While in the control class applying learning using conventional methods, in this class, students are asked to pay attention to the explanations of researchers with conventional methods, without using Google Earth, so that makes students bored and tired. Students only get information from the teacher. Some students ask questions, but many students are passive during the learning process. So it is not enough to pay more attention to assist students in developing 
spatial thinking skills and cause understanding of the material in the control class can not be maximized, this is seen from the results of students' posttest.

This study uses two data collection techniques, namely, documentation and test techniques. The test questions that were given in the sample class had previously been tested for validity and reliability. Test questions are given as many as 20 multiple-choice questions. The question is made by adjusting the indicators of spatial thinking ability consisting of location, condition, connection, comparison, aura, region, hierarchy, transition, analogy, pattern, spatial association.

\section{Results and Discussion}

Tests are given at the end of learning (posttest). Meanwhile, documentation is used to support research data in the form of test result data and learning documentation. The results of the experimental and control class posttest can be seen in Figure 1 below.

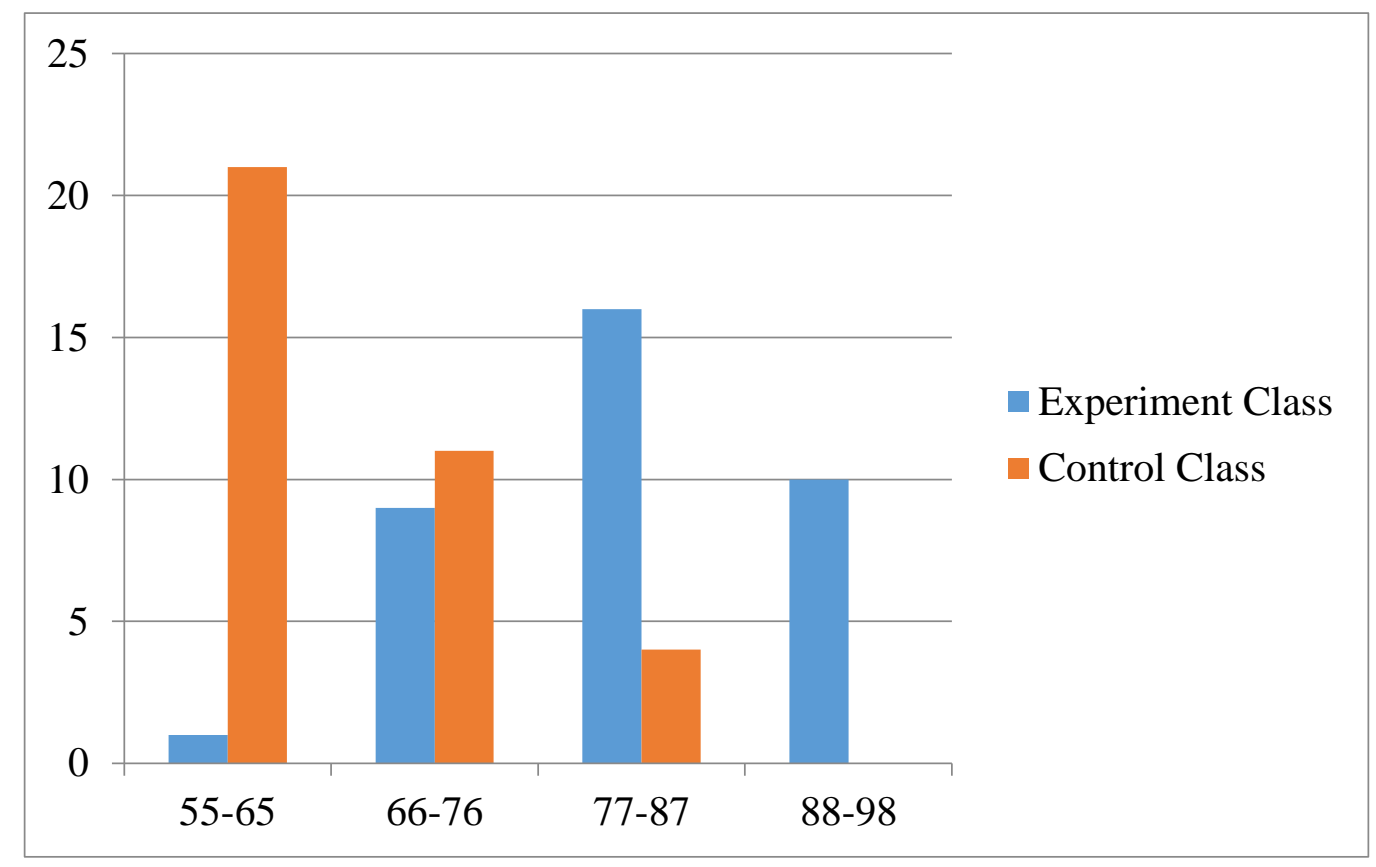

Figure 1. Post Test Results Students in the experimental and control classes

Based on Figure 1. shows that in the experimental class and the control class gets a variety of values. However, in the control class, many students received grades at intervals of 5565 , and none of the students received grades at intervals of 88-98. Students in the experimental class get the highest value of 95 , the lowest value of 65 , and the average value obtained by the 
experimental class is 82.92. Meanwhile, the control class test results with the highest score of 85, the lowest score of 55 and the average value obtained by the control class is 66.39. This is proof that the results of experimental class tests using Google Earth can affect student learning outcomes. In contrast, Verma and Estaville; Jo and Hong (2018) revealed that currently, there is no evidence of empirical research that shows that learning geography helps students develop spatial thinking skills.

To find out whether the data is normally distributed or not, then the normality test is done using Shapiro Wilk, with the help of a computer with the Statistical Package for Social Science (SPSS) version 20. The data criteria are said to be normal if significance>0.05. The results of data processing using the Shapiro Wilk technique can be seen in table 1 below.

Table 1. Distribution of Normality Test Results with the Shapiro Wilk Test

\begin{tabular}{|c|c|c|c|c|c|c|c|}
\hline & \multirow[t]{2}{*}{ Class } & \multicolumn{3}{|c|}{$\begin{array}{c}\text { Kolmogorov- } \\
\text { Smirnov }^{\mathrm{a}}\end{array}$} & \multicolumn{3}{|c|}{ Shapiro-Wilk } \\
\hline & & Statistic & Df & Sig. & Statistic & Df & Sig. \\
\hline \multirow{2}{*}{$\begin{array}{l}\text { Spatial Thinking } \\
\text { Ability }\end{array}$} & $\begin{array}{c}\text { Posttest } \\
\text { Experimen }\end{array}$ & .131 & 36 & .123 & .945 & 36 & .073 \\
\hline & $\begin{array}{l}\text { Posttest } \\
\text { Control }\end{array}$ & .150 & 36 & .039 & .928 & 36 & .021 \\
\hline \multicolumn{8}{|c|}{ a. Lilliefors Significance Correction } \\
\hline
\end{tabular}

Based on table 1. The normality of the test results above is known that the results of the experimental group posttest significance value (Sig) on the posttest score of the experimental class $0.73>0.05$ while the posttest score of the control class $0.21>0.05$. This shows that the data is normally distributed because the significance is $0.21>0.05$. Therefore it can be concluded that both are normally distributed.

Next, to find out whether or not some of the variants of the research data were tested for homogeneity. Criteria for decision making 0.05. In this homogeneity test, the researchers used SPSS 20. The results of the homogeneity test can be seen in the following table. 
Sri Rahayu et al / GEOSI Vol 4 No 3 (2019) 291-301

Table 2. Distribution of Homogeneity Test Results

\begin{tabular}{|c|c|c|c|c|c|c|}
\hline & & & Levene Statistic & df1 & df 2 & Sig. \\
\hline \multirow{4}{*}{$\begin{array}{l}\text { Spatial } \\
\text { Ability }\end{array}$} & \multirow{4}{*}{ Thinking } & Based on Mean & .000 & 1 & 70 & .983 \\
\hline & & Based on Median & .013 & 1 & 70 & .908 \\
\hline & & $\begin{array}{l}\text { Based on Median and } \\
\text { with adiusted df }\end{array}$ & .013 & 1 & $\begin{array}{c}69.59 \\
1\end{array}$ & .908 \\
\hline & & $\begin{array}{l}\text { Based on trimmed } \\
\text { mean }\end{array}$ & .005 & 1 & 70 & .942 \\
\hline
\end{tabular}

Based on table 2, it is known that the results of the posttest of the experimental and control groups, obtained a significance value of $0.983>0.05$, it can be concluded that the variants of the experimental and control groups are homogeneous. After observing the characteristics of the variables that have been studied and the requirements of the analysis, then testing the hypothesis. For the purposes of the hypothesis, inferential statistics are used with the help of SPSS version 20, namely t-test statistics. The decision-making criteria are as follows:

If $\mathrm{Sig}>0.05$, Ho is accepted

If $\mathrm{Sig}<0.05$ then Ho is rejected

Hypothesis testing, the step taken is to analyze the results of the t-test. The results of the $t$ test analysis can be seen in table 3 .

Table 3. Experiment and Control Posttest T-Test Results

\begin{tabular}{llllllll}
\hline & Mean & $\begin{array}{l}\text { Std. } \\
\text { Deviation }\end{array}$ & Df & $\mathrm{t}_{\text {hitung }}$ & $\mathrm{t}_{\text {tabel }}$ & $\begin{array}{l}\text { Sig (2- } \\
\text { tailed) }\end{array}$ & Conclusion \\
\hline Experimen & 82,92 & 7.962 & 70 & 8.651 & 1.666 & .000 & $\mathrm{H}_{\text {orejected }}$ \\
Control & 66,39 & 8.247 & & & & & \\
\hline
\end{tabular}

Ardyodyantoro's research results (2014) on "Utilization of Google Earth in Geography Learning To Improve Student Learning Outcomes of Class X High School Widya Kutoarjo" shows that learning using Google Earth media is effective in improving learning outcomes in geography. Learning outcomes with Google Earth media are higher than learning outcomes with lectures. The mean value of learning outcomes with Google Earth media 83,397, while with lectures 78,348. Improved learning outcomes indicated by the achievement score of 0.68 
improvements in the experimental class and 0.58 in the control class. $\mathrm{P}$ value of learning outcomes $0.01<0.05$, then $\mathrm{Ha}$ is accepted and $\mathrm{H} 0$ is rejected. This proves that the use of Google Earth media in learning geography is effective in improving the learning outcomes of class $\mathrm{X}$ high school students Widya Kutoarjo.

Isnaini's research results (2015) on "Comparative Use of Google Earth Media with Digital Maps on Class XI IPS Fauna Distribution Materials in State High School 1 Semarang" shows that (right-side t-test) shows a tcount of 2,433 and a table of 1.67 with a significance level of $5 \%$ and $\mathrm{dk}=31+31-2=60$, because tcount $>$ ttable, it was concluded that the experimental group taught using the Google Earth media the learning outcomes were better than the control group taught using digital map media. This means that the research hypothesis was accepted.

Meanwhile, Nofirman (2018) conducted a study on the geographical spatial ability of class XII students of SMA Negeri 6 Bengkulu City showing that the results of data processing it was found that the spatial abilities of class XII students at SMAN 6 Bengkulu there is in the largest group (43.55\%). The potential geographic spatial ability of class XII students in City 6 of Bengkulu City on the group with the largest number of $38.71 \%$. The average position is in the highest score group.

Furthermore, the results of Ervina, Asyik and Mizwar (2012) research on "The Influence of the Use of Google Earth and Maps Media in the Improvement of Geography Learning Outcomes in Material of Southeast Asian Regional At SMA Negeri 14 Bandar Lampung in the Academic Year 2011/2012" shows that there are differences in the increase in results student learning and the value of student learning outcomes on the use of google earth media is higher than the use of media maps.

Meanwhile, the results of Oktavianto, et al (2017) research on "The Effect of Google Earth Assist Project Based Learning to Spatial Thinking Ability" shows that Google Earth-aided project-based learning has a significant effect on students' spatial thinking skills. In addition, also found several advantages of Google earth-based project-based learning, including: (1) encouraging students to be solve real problems through project activities, (2) students are more active in learning, (3) student performance in completing projects are more organized, (4) students have more freedom to complete projects, (5) students are motivated to compete to produce the best products, and (6) students experience increased spatial thinking skills. 
The use of google earth in learning geography has an effect to students on spatial thinking ability indicated by an increase in student learning outcomes after using google earth while learning. In addition, student activities and attention increase and students' difficulty in understanding spatial decreases.

\section{Conclusion}

Based on the results of research, it can be concluded that there is a significant influence between the use of google earth on the spatial thinking abilities of students in class X SMA PGRI 2 Palembang. Judging from the average value of the experimental class's posttest is 82.92 and the posttest of the control class is 66.39. This has been proven by examiners that the t-count $\mathrm{Ha}$ is accepted, that's indicating that there are differences in the spatial thinking ability of the experimental group students who are treated using google earth during the learning process. The significance of the results of the posttest t-test from the two experimental and control groups was 0.000, and then the null hypothesis Ho was declared rejected because, based on the t-test criteria, the significance value was $<0.05$ or the Sig (2-tailed) value of 0,000 was obtained $<0.05$.

\section{Conflict of Interest}

The authors declare that there is no conflict of interest with any financial organization regarding the material discussed in the article.

\section{References}

Aliman, Mutia, \& Yustesia. (2018). Integrasi Kebangsaan Dalam Tes Berpikir Spasial. Jurnal Geografi FKIP UMP , 82-89.

Arikunto, S. (2010). Prosedur Penelitian Suatu Pendekatan Praktik. Jakarta: Rineka Cipta.

Ardyodyantoro, Gatty. (2014). Pemanfaatan Google Earth Dalam Pembelajaran Geografi Untuk Meningkatkan Hasil Belajar Siswa Kelas X SMA Widya Kutoarjo. Skripsi. Program Studi Pendidikan Geografi Fakultas Ilmu Sosial Universitas Negeri Yogyakarta.

Cuviello, Matthew P. (2010). Evaluating Google Earth in the Classroom. New York : Center for Teaching Excellence 
Ervina, E., Asyik, B., \& Miswar, D. (2012). Pengaruh Penggunaan Media Google Earth Dan Peta Terhadap Peningkatan Hasil Belajar Geografi. JPG (Jurnal Penelitian Geografi), 1(1).

Hidayat, K. N., \& Fiantika, F. R. (2017). Analisis Proses Berfikir Spasial Siswa Pada Materi Geometri. Prosiding Si Manis (Seminar Nasional Integrasi Matematika dan Nilai Islami) , 385-394.

Isnaini, N. (2018). Komparasi Penggunaan Media Google Earth Dengan Peta Digital Pada Materi Persebaran Fauna Kelas XI IPS di SMA Negeri 1 Semarang. Jurnal Geografi: Media Informasi Pengembangan Dan Profesi Kegeografian, 12(1), 52-61.

Jo, I., \& Hong, J. E. (2018). Geography Education, Spatial Thinking, and Geospatial Technologies: Introduction to the Special Issue. International Journal of Geospatial and Environmental Research, 5(3), 1.

Liu, R., Greene, R., Li, X., Wang, T., Lu, M., \& Xu, Y. (2019). Comparing Geoinformation and Geography Students' Spatial Thinking Skills with a Human-Geography Pedagogical Approach in a Chinese Context. Sustainability, 11(20), 5573. doi:10.3390/su11205573

Nofirman, N. (2019). Studi Kemampuan Spasial Geografi Siswa Kelas XII SMA Negeri 6 Kota Bengkulu. Jurnal Georafflesia: Artikel Ilmiah Pendidikan Geografi, 3(2), 11-24.

Oktavianto, D. A. (2017). Pengaruh Pembelajaran Berbasis Proyek Berbantuan Google Earth Terhadap Keterampilan Berpikir Spasial. Jurnal Teknodik, 21(1), 059.

Patterson, T. C. (2007). Google Earth as a (Not Just) Geography Education Tool. Journal of Geography, 106(4), 145-152. doi:10.1080/00221340701678032

Setiawan, I. (2016). Peran Sistem Informasi Geografis (Sig) Dalam Meningkatkan Kemampuan Berpikir Spasial (Spatial Thinking). Jurnal Geografi Gea, 15(1). doi:10.17509/gea.v15i1.4187

Sugiyono. (2010). Metode Penelitian Pendidikan Pendekatan Kuantitatif, kualitatif, dan R\&D. Bandung: Alfabeta.

Sudjana. (2005). Metode Statistika. Bandung: Tarsito.

Yousman, Y. (2008). Google Earth. Yogyakarta: C.V Andi. 